\title{
Postcolonial and post-racial runners: the rise of African and African-American athletes in society
}

\begin{abstract}
Many sports and urban leisure's appear as a part of a global black culture. Through this anthropological research we interest to the athletic phenomenon in which African and african american are such involved. It deals with sport and colonialism, sport and postcolonial societies, sport and color line. For 1930s, in western world the representations refer black men to the most popular activities (sportsmen, dancers, rappers). Also, we have a tendency to associate sprint culture with carribbean people, football with western african and music with african american lower-class. The participant observation reveals that the Afro descendants living in western societies (USA) and the european from immigrant families (France) have integrated these positives representations and strengthen these prejudices. Some sociologists as John Hoberman or Harry Edwards criticizes this attitude, ${ }^{1,2}$ the last accuses black communities to betray their youth. This study bases oneself on ethnography of track and field and completed with an historical approach of body, a lot of archives in sport, cultural studies and data from the Olympic museum.
\end{abstract}

Keywords: track and field, army, athletes, sport, masculinity, african, french, race, sprint
Volume 3 Issue I - 2018

\section{Yaya Koné}

University of the Littoral Opal Coast, France

Correspondence: Yaya Koné, University of the Littoral Opal Coast, France, Tel 33633647834, Email yaya.kone@hotmail.fr

Received: July 18, 2017| Published: February 15, 2018

\section{Introduction}

In track and field the masculinity reveals in several points. The sprinters have to put up with social environment pressure. Into the African families the first place is the only position conceivable. Contrary to throwing and pole vault, track and field disciplines are dominated by black athletes from Americas (powerful sprinters from Jamaica and USA) and eastern Africa (1500 m, Marathon, from Kenya and Ethiopia). Some people from western African assert that the eastern African athletes do not represent a model of masculinity. Contrary to sprinters, Kenyan athletes would be thin, too weak or fragile. During the decade 1980s the champion Carl Lewis has become a legend. Lewis represents ideals of aesthetic and value, versus the bad, the ugly and outlaw Ben Johnson. The $100 \mathrm{~m}$ race appears like a duel between two black men: Lewis coming from a middle class family of Alabama and Pennsylvania, and Ben Johnson from Ontario working-class, son of Jamaican immigrants. This study focuses both on the ethnicity, representations and manliness through sports.

\section{Blackness and athletics}

The question of blackness is expressive through the sport phenomenon. We interest mainly to the case of track and field athletes. The historical and sociological analysis of sport both in Africa, Europe or United States put in evidence the racial context and colonial and postcolonial relationships as fear of European settlers to be defeated by African natives in physical activity. At the beginning of 20th century, in French western Africa, French Equatorial Africa, Algeria, Tunisia and Morocco, indigenous are not allowed to do sport. The first club is founded in 1905 in Conakry (Guinea), but it's only after the World War I that French colonial authorities see in the teaching of physical education a way to constitute a fish pond of soldiers for the national army, "the African shooters". ${ }^{3}$ During the World War II African soldiers are well known under the name of tiraillleurs sénégalais, but Germans qualify these soldiers as "black shame". According to the Reich III authorities african and africanamerican are degenerated people. The World War II reveals to the most of european that Senegalese or Kanak are not the salvages naked exhibited during the colonial expositions. In the same time we note that war has broken the image of settlers, African people don't believe to the physical and political superiority of white settlers anymore. The great participation of African shooters to the World War I and World War II bring about the end of the myth of European invisibility.

\section{The pioneers}

As many educators and soldiers, the French army officer Georges Hebert and the british officer Baden Powell, were inspired by physical education and aesthetic of African and Caribbean people. The officer Georges Hebert was fascinated by indigenous bodies and way of life. He traveled all over the world; he was in Martinique in 1902, the year of the eruption of the Mount Pelé. After the disaster he observes that the survivors are the strongest men, and establishes the link between survival and physical constitution.

Many educators and politician like Hebert or Pierre de Coubertin evokes (Brohm) the crisis of education, they argue that the weakness of the youth explains the defeat of 1870, against Germany. They put the emergency to reinforce the nation teaching physical education and soldier training to the pupils. Taking example on indigenous of Africa and Caribbean, Hebert founds a new method of physical education called Natural Method. Also he makes Le parcours du combattant for soldiers training.

Battling Siki is a native of Senegal. He grew up into the Sereer society, well known for the practice of traditional wrestling called Senegalese Wrestling. Wrestling is a traditional practice in West Africa, in Mali, Niger, Togo, but is most popular in Senegal. In this country the champions become heroes, the most famous wrestler is Tyson. The story of Siki reminds the life of the African American prize-fighter Tom Molineaux against Tom Cribb in 1810 or the case of the Congolese boxer Wangu, assassinated, lynched by racists in a street of Berlin. In 1922, the Senegalese boxer Battling Siki defeats the French star Georges Carpentier. As a result French boxing federation decides to banish Siki (Danthu-Deville). 
The Mouloudia Club is the first club allowed to indigenous; it was founded in 1921 in Algiers. Follow the mixed clubs in Senegal, French Sudan (Mali) and Ivory Coast. The missionaries called Pères Blancs give an impetus to the sport in French Sudan. Since El Ouafi in 1928 to Zidane 1998, for long times France use algerian athletes and their descendants in national sport. In 1928 the Algerian Boughera El Ouafi wins the Marathon race during the Olympic Games in Amsterdam. For the first time French voices and many journalists talk about the eventual superiority in running of African athletes than white athletes and evoke the opportunity to use people from North Africa in order to win more medals. The first broadcasted Olympic games in Berlin have shown the limits of Aryan theories. In 1936, the athletes crossed the boundaries lines. The Fuhrer Adolf Hitler could not stand to see the Aryan virility humiliated by the african American athletes. With his four gold medals the sprinter Jesse Owens has refuted Nazi racial theories. ${ }^{4}$ This major event launches the black athletic machine; it starts the Myth of Black Athlete, the belief of a black superiority in track and field mainly in running race, and it launches the 'muscular assimilationism' phenomenon of black people. African American and Caribbean athletes are strongly involved in profitable sports. ${ }^{4}$

After Owens and Metclafe's victories the French authorities decided to organize several days of detection towards athletes of western Africa. Thinking by association, according to the French if the African American succeeds easily to defeat the usual enemy of France, likely West African could do the same. But the detection test organized in French Sudan remains unsuccessful. The african athletes and African sport have emerge in 1950. In the Atlanta 1996 Olympic games, Marie José Perec has won two gold medals for France (200$400 \mathrm{~m}$ ). Confronted to the victory of this athlete from Guadeloupe, Jean Marie Le Pen, the leader of far right party asserts that he recognizes black's physical superiority through sports, but only in sports adding that Blacks are not able to build castel, pyramid or cathedral. We note some differencies between black communities according they live in Africa or as minorities in Western World for people living in Paris being black means being strong, cool, warrior and dominated. For all it seems obvious that black man defeat white athlete in track and field. The archives show the inversion of the representations. Indeed, at the beginning of the 20th century, everybody considered that black people were not able to defeat European in sport.

\section{Sport, honour and virility}

Doing a real anthropology of sense we notice that every society get a cultural repertory of emotion, the reaction depends on the culture, the period and further parameters. Nowadays, the indifference in front a person swimming with a bikini contrast to the situation at the end of nineteenth century (Victorian), before it was only allowed to go on the beach with a slip recovering all the sides of the body. In the same period the Germans settlers forced Herero from Namibia to wear sweeping clothes. Western settlers didn't respect the culture and beliefs of people living in Africa. And yet, some activities were not conceivable for the members of Sahelian societies. Many African refused to do sport, mainly running. They considered running as a practice of children. Also it represents a lack of virility; running is regularly associated to negative things, to run away (Table 1). And to do exercises in short is a shame; it calls into question their dignity. People from Sahelian countries as Mali, Burkina Faso or Niger can't stand to see an adult bare-chested or playing like children do.

Fulbe society lives all over Sahelian Africa, from Sénégal to Cameroun (Fulani, Pular) from Tchad and Sudan to Central African
Republic (Fullah). Fulani living in Mali and Guinea refer to a code of honour called Pulaako. The main principles of Pullako are intelligence, shame and sobriety. The individual who don't respect these principles cannot be Fulbe. The Fulbe are conspicuous for their attitude or gesture. It is a distinctive sign than other ethnic groups (Bamana, Mandinka). Pulaako rules the social order, the submission of women and the masculinity of men. According to the Pulaako a Fulbe doesn't have to wear short, to be weak and to be sentimental. The Fulbe people met in Bamako assert that not live according the Pulaako means a lack of education. They wear large traditional clothes called Boubou, Bazin or Delekiba. The continence, the control of emotion, body and language are essential. Because they are Fulbe and muslim, nowadays many families from Sahel area can't stand to see athletes doing sport, mainly women. In Bamako a religious conservative community tries to influence and rules the society, the Wahabbia community forbids to do all activities not connected to the religion, their critics focus on music, sport and leisure.

What does Cisse the old Wahabbia think about runners?

a. It's a shame to have this behaviour

b. The runners behave like children

c. A man should not behave this way

Table I Female athletes and male dignity (average)

\begin{tabular}{llll}
\hline $100 \mathrm{~m}$ & Championship & $\begin{array}{l}\text { Regional } \\
\text { championship }\end{array}$ & $\begin{array}{l}\text { National world } \\
\text { championship }\end{array}$ \\
\hline $\begin{array}{l}\text { Women } \\
\text { best time }\end{array}$ & 11 "60 & II”20 & 10 "96 \\
$\begin{array}{l}\text { Men worst } \\
\text { time }\end{array}$ & 12 "20 & II”05 & 11 "30 \\
\hline
\end{tabular}

We observe in Mali and Burkina Faso a low number of adults who practice running. In the poorest districts of Bamako, Bobo Dioulasso and Sikasso, some inhabitants are not allowed to run. Men who get married have to stop leisure as running, associated with childhood. Even among track and field athletes those get married do not sport anymore. Men stop running when they hold the head of a family. The sportswomen are early retired, they can't remain athletes and the society imposes them to stop running.

\section{Black only?}

Until the 1932 Olympic Games in Los Angeles, the whole of the gold medals in sprint are won by white athletes. The dominated people from Africa and minorities from America don't perform in major competition. The win of the sprinters Eddie Tolan, Jesse Owens and the boxer Joe Louis will be a sign heralding black champion. In 2010 the French sprinter Christophe Lemaitre runs the $100 \mathrm{~m}$ in 9"98. Doing a real raciology of sprint the journalists call him by the nickname of "the fastest white man of the world". Lemaitre has crossed the color line (Before him the Norwegian Geir Moen in 1994 and the Australian Matt Shirvington in 1999, the French Christophe Lemaitre 9"97 in $100 \mathrm{~m}$ in 2010). ${ }^{5}$ According to the journalists, it's the first time that a white athlete runs the $100 \mathrm{~m}$ under 10 seconds. For the industrial revolution of nineteenth century, modern societies need to product champion, to break records or performance, in running the time has become an important stake. We forget that in the struggle of sprint the essential question should be about (which one?) the winner and not about the time (which time?). White little man against strong 
black men, it seems unfair. If we recognize that at in the competition women cannot run against men, why do people consider that black and white athletes don't play the same competition? Yet, as the greatest track and field champions, Christophe Lemaitre has won world and European youth championship both in 200 and $100 \mathrm{~m}$ races $(2008$, 2009). And contrary to many French track athletes he has confirmed.

The three periods of sprint $100 \mathrm{~m}$ :

a. White domination, until 1932 (Table 2)

b. A period of transition between 1936 and 1972

c. A black domination since 1976 (Table 3)

Table 2 From W.A.S.P to jamaican sprinters

\begin{tabular}{|c|c|c|c|}
\hline $\begin{array}{l}\text { I00 M olympic } \\
\text { champions }\end{array}$ & $\begin{array}{l}\text { African } \\
\text { descendants }\end{array}$ & $\begin{array}{l}\text { European } \\
\text { descendants }\end{array}$ & Federation \\
\hline 1896 & & Burke & USA \\
\hline 1900 & & Jarvis & USA \\
\hline 1904 & & Hahn & USA \\
\hline 1906 & & Hahn & USA \\
\hline 1908 & & Walker & SAF \\
\hline 1912 & & Craig & USA \\
\hline 1920 & & Paddock & USA \\
\hline 1924 & & Abrahams & GBR \\
\hline 1928 & & Williams & CAN \\
\hline 1932 & Tolan & & USA \\
\hline 1936 & Owens & & USA \\
\hline 1948 & Dillard & & USA \\
\hline 1952 & & Remigino & USA \\
\hline 1956 & & Morrow & USA \\
\hline 1960 & & Hary & GER \\
\hline 1964 & Hayes & & USA \\
\hline 1968 & Hines & & USA \\
\hline 1972 & & Borzov & URSS \\
\hline 1976 & Crawford & & TRI \\
\hline 1980 & & Wells & GBR \\
\hline 1984 & Lewis & & USA \\
\hline 1988 & Lewis & & USA \\
\hline 1992 & Christie & & GBR \\
\hline 1996 & Bailey & & CAN \\
\hline 2000 & Greene & & USA \\
\hline 2004 & Gatlin & & USA \\
\hline 2008 & Bolt & & JAM \\
\hline Total & 13 & 14 & 27 \\
\hline
\end{tabular}

Table 3 Black domination

\begin{tabular}{lll}
\hline $\mathbf{1 0 0} \mathbf{~ m}$ & African descendants & $\begin{array}{l}\text { European } \\
\text { descendants }\end{array}$ \\
\hline World record & 9 9"58 Bolt & \\
European record & 9 966 Obikwelu/Vicaut & \\
World junior record & $10 " 02$ Brown & \\
European Junior record & 10"04 Lemaitre \\
French record & 9 97, 9"92 Lemaitre \\
& & Vicaut 9"86 \\
\hline
\end{tabular}

Through a period of one century we note the unequal distribution of Olympic medals. For long time white students from upper class (WASP) won the olympic title. But gradually athletes from different ethnic groups reach to the podium, as Jews (Abrahams), AfricanAmerican students (Dillard, in Roos), Italian immigrants (Remigino), Ukrainian (Borzov) and Caribbean athletes, mainly sprinters from Jamaican diaspora (Table 3). Black domination in track and field is not an advantage get from Mother Nature. It results to different choices of society to develop a sprint culture (Black Americas) or a marathon culture (Eastern Africa). Ideology, nationalism and empowerment constitute main factors of running. Track and field appears as a way to sort of out of poverty for Ethiopian from Arsis country. It's a social opportunity for working class teenagers from London, Paris and Los Angeles (Bourdieu). French afro descendants living in the suburbs claim to have most chance to succeed in sport than otherwise carreer. A field survey led in French clubs shows that black athletes invest more in track and field than white athletes; they have self confidence and they believe in predestination (Carrington). In the same group of Parisian sprinters, we notice that the most of black athletes are unskilled worker or jobless whereas white athletes are students, physical education teachers. In Jamaica schooling and athletics are linked, the Boys and Girls championships contribute to the excellence of Jamaican youth in track of field.

Ancient Greek Olympic motto: "The crown or the death" The final of men $100 \mathrm{~m}$, the great moment of the Olympic Games 1988:
a. Muscles
b. Testosterone
c. Revenge, hatred
d. World record
e. The show

The charismatic Carl Lewis was famous thanks to his style, all over the world the youth tried to run imitating the gesture of Lewis. He launches the fashion of Carl Lewis haircut. Every Casanova from Ghana, Ivory Coast, United Kingdom and France asked haircutters the Carl Lewis haircut. Coming from the middle class, the smiling Carl Lewis was not a model of masculinity; we could compare him to the king of the 1980's pop Michael Jackson. The opponent, Ben Johnson alias the 'bull' played the role of the bad boy, never smiling, always angry. Like usually in the tales we find the fight between the good and the evil, the God of stadium and the devil. The powerful Ben convicted of doping (testosterone, stanozol), the skilful Carl, Hero of the prior Olympics. Today we know that further athletes failed drug test, among them likely Carl Lewis. But the most famous track athlete 
of the world was protected both by his federation and the IAAF (International Athletic Amateur Federation).

With the 1990s begins the reign of black muscles in the sprint. The movement was launched by the Black British Lindford Christie (born in Jamaica). Because the final of sprint represents the confrontation between eight black men, it represents black masculinities, black bodies. Christies was celebrated for his velocity but also for his body. He looks like a gladiator, after each heat and final he reveals his body. In the 1993 world championship, he plays the role of the "killer of track", (Table 4) concentration and look of killer in the starting blocks, imitation of John Wayne drawing his gun at the arrival.

Table 4 Silver medallists:The loser's magnifiques

\begin{tabular}{|c|c|c|c|}
\hline $\begin{array}{l}100 \mathrm{M} \text { second } \\
\text { places }\end{array}$ & $\begin{array}{l}\text { African } \\
\text { descendants }\end{array}$ & $\begin{array}{l}\text { European } \\
\text { descendants }\end{array}$ & Federation \\
\hline 1896 & & Hoffman & GER \\
\hline 1900 & & Tewksbury & USA \\
\hline 1904 & & Cartmell & USA \\
\hline 1906 & & Moulton & USA \\
\hline 1908 & & Rector & USA \\
\hline 1912 & & Meyer & USA \\
\hline 1920 & & Kirksey & USA \\
\hline 1924 & & Sholz & USA \\
\hline 1928 & & London & GBR \\
\hline 1932 & Metcalfe & & USA \\
\hline 1936 & Metcalfe & & USA \\
\hline 1948 & Ewell & & USA \\
\hline 1952 & Mc Kenley & & JAM \\
\hline 1956 & & Baker & USA \\
\hline 1960 & & Sime & USA \\
\hline 1964 & Figuerola & & CUB \\
\hline 1968 & Miller & & JAM \\
\hline 1972 & Taylor & & USA \\
\hline 1976 & Quarrie & & JAM \\
\hline 1980 & Leonard & & CUB \\
\hline 1984 & Graddy & & USA \\
\hline 1988 & Christie & & GBR \\
\hline 1992 & Fredericks & & NAM \\
\hline 1996 & Fredericks & & NAM \\
\hline 2000 & Boldon & & TRI \\
\hline 2004 & Obikwelu & & POR \\
\hline 2008 & Thompson & & TRI \\
\hline Total & 18 & 9 & 27 \\
\hline
\end{tabular}

In despite of the victory of the Black Canadian Donovan Bailey, in 1996 Olympic games the real winner was Christie. In effect, after his disqualification he stood into the stadium showing his muscles, this event was broadcasted all over the world and strengthened the image of black masculinity in Track and field.

a. They represent muscular monuments!" "I have never seen so many muscles

b. A French Woman: "I don't like sport but I love watch the bodies of black athletes

c. A French man: "Black men are the fastest because they have bigger muscles than other

A sprinter with muscles makes impression. From regional competitions to Olympic Games we observe that the winners are not those who get the biggest muscles. Everyone could run in $100 \mathrm{~m}$, fit one as Lewis, tall as Usain Bolt, small as Andre Cason or Maurice Greene, white as Christophe Lemaitre, Valeri Borzov, Bobby Morrow, Allan Wells, muscular as Lindford Christie. The advertising exploited this image, this 'black athletic aesthetic' to promote their products, T-shirts, sneakers. In the advertising black athletes represent the force of nature, they compared Christies to a black panther (Puma), Carl Lewis and Marie José Perec compared to the Greek heroes, (Heracles) better than all machines (Pirelli, Citroen). Into Black community's people was disappointed and shocked to see Carl Lewis dressed as a women in advertising. Some athletes remind both the rappers of the 1980s and their sun glasses (Easy-E, Flavor Flaves or Terminator $\mathrm{X}$ ) and the rappers of the 2000s showing their muscles (DMX or 50 Cent). Maurice Greene and Ato Boldon, gold and silver medallists on $100 \mathrm{~m}$ at the Sidney 2000 Olympics, wanted to afraid their competitors. Greene played the role of bad boy, showing his tattoo (Pitbull). His gesture and attitude meant: 'I am the best and I'll kill you' (as Mohamed Ali, in Sammons).

The tattoo means of sprinters:

a. The achievement of body

b. The membership, the affiliation with a group

c. The quality of the predator

In Paris, Jean, a track athlete did tattoo his body with a Cheetah. Since several years he failed to improve his performances. He asserts that he wants to get the velocity of the fastest animal.

\section{The African domination}

African athletes of Kenya and Ethiopia don't represent black masculinity as sprinters, some journalists and scientists claim that they win because of a genetic advantage, just an argument to explain the black domination in track and field. We note that all Ethiopian athletes come from one region of Ethiopia: The Arsis. The Ethiopian school of long distance runners has begun with the exploit of Abebe Bikila in Olympics 1960 in the territory of the enemy of Ethiopia, Italy. Bikila became a hero of the nation and an example for the youth of Arsi, following Bikila: Yifter, Wolde, Derartu Tulu, Gebreselassie and Kenisa Bekele. In Kenya, the Kalenji society, from eastern Kenya is well represented in track and field, since the victory of Kip Keino in the Olympics 1968. The birth of heroes and politics towards track and field, this is the secret of Kenyan, Ethiopian and Jamaican dominations (Table 3) (Table 5):

a. Where are the inhabitants of Nepalese Mountains?

b. Where are the black athletes from France, Netherlands, Liberia, Mali and Brazil or Italy? Why some have chosen football? 
Table 5 The gap

\begin{tabular}{lll}
\hline Rank & Black fastest men & White fastest men \\
\hline I & Bolt 9"58 & Lemaitre 9"97 \\
2 & Gay & Woronin \\
3 & Powell & Mennea \\
4 & Carter & Shirvington \\
5 & Greene & Macrozonaris \\
6 & Montgomery, Johnson, Bailey, & Moen 10"09 \\
\end{tabular}

The Jamaican Usain Bolt seems confirm the black superiority, but contrary to his predecessors he runs such above his competitors, no one duel is possible, then he makes the show, not playing on his masculinity, but enjoying the stadium, being funny opposite to the serious of the former killers of the field.

\section{About women}

Contrary to men, in Mali, women practicing $100 \mathrm{~m}$ have not chance to become heroes and their body sculpted by sport is criticized. During a field work in Western Africa we noticed the attitude of people watching races of women. "She's not pretty" "look her she looks like a man", "I don't like this kind of women", "she's a drag". Watching Lindford Christie or Greene, they said:"beautiful!", "he's amazing", "What a body of warrior". We have watched a scene in a district of Abidjan; people had an argument about the athletic body of a girl. It may men fear to lost their masculinity in front of women.

Because the intensive practice sculpts the body of girls, many people assert women who do sport, mainly track and field, are not female. The history of Athletics presents many example of the question of gender. In the ancient Greece the Olympic Games were forbidden to women, the athletes and their coaches were naked it was the best way to avoid the presence of women. Stella Walsh born Walasiewicz was a polish athlete naturalized American (Harris), she was winner of the $100 \mathrm{~m}$ during the 1932 Olympic Games. She died in 1980; the autopsy revealed she had a rare condition known as mosaicism, which involves ambiguous sexual organs'. She was a man. To fight the cheat, the institutions and IAAF, created different tests like the test Barr in 1966. In the 2009 world Berlin championship, the South African Caster Semenya, winner of $800 \mathrm{~m}$ (women) was accused to be a man. The separation between men and women is also a way to protect men virility and men dignity (Table 1). However, in many societies like Senufo, every work is carried out by women. Senufo people say "even child, the man is older than women"; it's the social order, but we notice that men don't want to be compared physically to a woman. During the regional and the international competitions some women are faster than men. For example in the world championship, fastest women are better than men from countries like Guinea, Mauritania or Indonesia. In the major championship, Olympic Games and World championship, the condition of selection are different, easier according to the country, is why it may to see athletes from developing countries, generally with low performance. In France, the champion and the vice champion are automatically selected but only if they have realized the time to go called "minima", usually they ran under the "minima" (10"35 for men). In France, every champion has realized 10" 15 or 10 "20 during the season; in Chad, 2 persons are chosen among the track athletes, their level is not important. In USA, the track athletes have to win the US selections. ${ }^{6-8}$

\section{Conclusion}

This anthropological and historical approach put in evidence the building of black consciousness and the representation of black bodies. These representations were inherited from the violence of colonial and slavery societies: The way to judge and control the body. It swings from rejection to fascination, between hatred and admiration. The body of indigenous was both qualified as degenerated by European eugenics, using as machine during slavery, and constantly compared to animals. With the birth of Black athletes in 1936, black people have seen in the body, the chance to go out of poverty, the better way to reach to social progress. Considered as inferior in further contexts, dominated both because is from working class and his Black; on the track, in the ring and even in the bed Black man is considered as superior: never equal. Excluded because of the color of their skin, the reference to the black pride has meant the freedom, but this is imprisoned in the prejudices and unfortunately the bodies and attitudes of athletes and singers are hostages of the sport business and music industry.

\section{Acknowledgements}

None.

\section{Conflict of interest}

Author declares that there is no conflict of interest.

\section{References}

1. Koné Y. Anthropologie de l'Athlétisme en Afrique de l'Ouest. Anthropology of Running in Western Africa, France ; 2011. p. 530.

2. Koné Y. Les determinants de la course à pied en Afrique Soudanosahélienne: de l'utlilitarisme à l'olympisme. Ph.D Dissertation, University of Paris, France; 2009.

3. Koné Y. The sport phenomenon in western Africa. Paper for EASA conference, Slovenia; 2008.

4. Edwards H. Sociology of sport. Dorsey Press, USA; 1994.

5. Douglas H. Race, culture and the revolt of Black Athlete: The 1968 Olympic protest and their Aftermath. University of Chicago Press, USA; 2003.

6. Bernadette DD. Le sport en noir et blanc, Du sport colonial au sport africain dans les anciens territoires français d'Afrique occidentale (19201965). L'Harmattan. France; 1997.

7. Alexandre R. Les athlètes africains-américains et les mouvements pour l'égalité racial. L'Harmattan, France; 2006.

8. Herbelot N. Sprinteur mais blanc. 2009. p. 9. 